\title{
The Challenges of Human Security in Sub- Saharan Africa: The Way Forward
}

\author{
Akpan, Nse Etim, $\mathrm{PhD}^{1}$; Edeki, John Enesi, $\mathrm{PhD}^{2}$; Nwokah, Imere Lordmizer ${ }^{3}$ \\ ${ }^{1}$ Department of Political Science, ${ }^{1}$ Federal University Wukari, Taraba State, Nigeria
E-mail: $\underline{\text { nseakpan04@ gmail.com }}$
${ }^{2}$ Agricultural Research Council of Nigeria, Mabushi, Abuja, FCT.
E:mail: $\underline{\text { edekijohnenesi@gmail.com }}$
${ }^{3}$ Department of Political Science, Federal University Wukari, Wukari, Taraba State \\ Email; imerenwokah@yahoo.com
}

\begin{abstract}
The increased interaction of societies on a global dimension evidently provides for the overall need for human security especially in the African continent where the number of conflicts is still overwhelming. This paper examined the challenges of human security in SubSaharan Africa with a view to suggesting the way forward. Anchored on a qualitative method and with reliance on secondary sources of data, it argued that there is need to better understand the nature of the rapidly evolving large-scale challenges that can have a major impact on individuals and populations. The paper further observed that it is imperative to strengthen the mobilization of wide range of actors involved in policy formulation that affects the unfolding dangers of human security in order to curtail them. It recommended the promotion of human capacity building in African states, assistance to states in the region to tackle HIV/AIDs and other contagious diseases, promoting the active participation of communities and representatives of civil society in the planning and implementation of development programs among others and concluded that though the challenges of human security in the continent are overwhelming, a proper implementation of these measures could ensure security for the vulnerable populations in the region.
\end{abstract}

Keywords-Challenges, Human Security, Sub-Saharan Africa, Civil Society, Conflicts.

\section{INTRODUCTION}

In Africa, the number of conflicts is still overwhelming as are the consequences for civilian population. In his address to the $37^{\text {th }}$ summit of the Organization of African Unity (OAU) now Africa Union (AU) in Lusaka, Zambia in July 2001, the then SecretaryGeneral of the United Nations, late Kofi Annan, warned that that "we are confronted with persistent conflicts and crises of governance and security that threaten to derail our hopes for an African Union of peace and prosperity (Annan, 2001). It is equally clear that the number of
African actors involved in conflict resolution and prevention has considerably increased as has their effectiveness, in particular in the framework of subregional initiative. However, one of the major issues is to explore the ways and means of enhancing that effectiveness at both regional and sub-regional levels. Indeed, lessons can be drawn from past and ongoing processes of negotiation and mediation with a view to reinforcing conflict prevention mechanisms, including discussions on the nature and purpose of an African peace-keeping force.

Human security is concerned with safeguarding and expanding the vital freedom of peoples. It requires both shielding people from acute threats and empowering people to take charge of their own lives with integrated policies that focus on people's survival, livelihood and dignity, during downturns as well as prosperity (Ogata, 2002). In addition to the persistent problems and vulnerabilities with which the world has long been familiar, there is a new wave of dramatic crises at the turn of the millennium related to terrorist attacks, ethnic violence, and epidemic of diverse forms including the dreaded Ebola virus as well as sudden economic downturns. There is also the fear that existing institutions and policies are not able to cope with weakening multilateralism, falling respect for human rights, eroding commitments to eradicate poverty and deprivation, outdated sectarian perspectives in education systems and the tendency to neglect global responsibilities in an increasingly interrelated world.

However, in Africa today, democratic principles and practices are deepening and gaining wider support. There has also been a massive increase in the role of civil society and community based organizations (CBOs) while the Sustainable Development Goals (SDGs) represent a major initiative aimed at removing deprivations on which efforts to improve human security can be built. But aside from this, the main challenge is to link prevention to the promotion of human security, on the basis of the common 
priorities already identified and on the widely shared concern for meeting the needs of the most vulnerable populations.

Thus, this paper attempts to answer four (4) basic questions: How can we ensure that major dimensions of human security will be taken into account in regional, sub-regional and international policies as the continent moves from the resolution of conflicts to the building of democratic and stable societies that respect all of human rights? To what extent has Africa adequately identified all the priorities that require long-term action, or is the continent limiting itself to dealing only with the most urgent matters? Which capacities should be built in order to move Africa forward in the promotion of human security particularly through education and training? What strategies could aid the mobilization of the most vulnerable populations, which must emerge as stakeholders in the democratic process through participation and dialogue? It is imperative that African leaders must understand that the growing uneasiness and frustration of the African populace is a result of leadership failure which often times results in armed violence.

\section{REVIEW OF SOME RELATED LITERATURE}

The "Human Security" approach contends that threats and challenges to security transcend national defence, law and order to encompass all political, economic and social issues that guarantee a life free from risk and fear. The focus of security has therefore shifted from the state to the security of persons which however is not mutually exclusive. Security can be thought of as a "public good", responding to the strategic need to support sustainable human development at the same time as promoting national, regional and global peace and security. Under colonial rule, African states and their security establishments were organized and administered according to European models. These formal models largely remained in place following independence, though in many cases more informal administrative and security structures developed parallel to the official ones. In the 1960s, the OAU confined state sovereignty within borders as defined under colonial rule thus, making most attempts to develop new and innovative security paradigms specifically relevant to African contexts a relatively recent event (Henk, 2008).

Contemporary African thinking on security is manifestly influenced by the UNDP Human Development Report and the experience of diverse National Poverty Reduction Programs, which prescribes that security institutions have a role to play in poverty reduction. However, as a survey of security system reforms by the
Organization for Economic Cooperation and Development (OECD) and Development Assistance Committee (DAC) unfolds, there are antecedents of the concept of human security to be found in African philosophies and discourse, for example the thoughts of Nkrumah and Senghor in West Africa, which argue for the primacy of basic human needs (Hutchful and Fayemi, 2004). By and large, there is consensus across Africa that security should be people centered which translates first and foremost to people's safety. This much was acknowledged by the OAU 1991 Kampala document, "Towards a Conference on Security, Stability, Development and Cooperation in Africa.

The document rightly observed that security embraces all aspects of the society including economic, political and social dimensions of individual, family, community, local and national life. The security of a nation must be constructed in terms of the security of the individual citizen to live in peace with access to basic necessities of life while fully participating in the affairs of his or her society in freedom and enjoying all fundamental human rights (OAU, 1991). Additionally, in 2001, the DAC Conflict, Peace and Development Cooperation Network CPDC) defined security as increasingly being viewed as an all-encompasing condition in which people and communities live in freedom, peace and safety, participate fully in the governance of their countries, enjoy the protection of fundamental rights, have access to resources and basic necessities of life, and inhabit an environment which is not detrimental to their health and wellbeing. In this case, both the security of people and the security of the state are mutually reinforcing (OECD, 2001).

Governance issues are central to human security in so far as a wide range of state and non-state institutions play a role, or have a role to play, in protecting people at different levels. Security can be seriously undermined where these security institutions are poorly managed and coordinated, or are not responsive to the needs of the population. Equally, the Commission on Human security (CHS) final report "Human Security Now" views human security as protecting vital freedoms. It means protecting people from critical and pervasive threats and situations, building on their strengths and aspirations, creating systems that give people the building blocks of survival, dignity and livelihood. Human security connects different types of freedoms, freedom from want and that to take action on ones' own behalf (Ogata and Sen, 2003). This aspect of security must also address the special needs of populations and the protection of victims, refugees and internally displaced persons. It also focused on the interrelations between insecurity and the need to ensure that development activities are maintained alongside 
conflict resolution initiatives. Thus, one of the primary roles of the state is to provide peace and security for its citizens both within the nation-state and to ensure their protection against threats from outside (Rugumamu, 1993).

As a matter of fact, most African governments have continued to consider security issues in terms of protecting the state, its institutions and frontiers, regime stability and military defence. This partly explains why, except perhaps in the case of South Africa, the concept of human security in its present form has come to be considered as donor-driven. Despite this perception, the OEDC/DAC survey indicates that human security represents an "ideal" or ultimate goal to which African populations aspire. However, African population considers that it is the state's primary duty to act to provide basic protection of life and property. Nonetheless, in many contexts, violence and or political disorder continue to be widespread, adding to the lack of confidence in the state's capacity to create the conditions for human security to be achieved.

\section{Some Theoretical Orientation}

Attempts have been made by scholars to provide an adequate conceptualization of human security. In order to properly understand the concept it is proper to place it within a particular framework of analysis in which case we adopt both the neo-realist and postmodernist theories of international relations. The neorealist theory maintains a continued emphasis on the primacy of the state within a broadened conceptualization of human security. This is what some scholars and analysts call the "new security thinking" (Thompson, 2000). The postmodernist or "critical human security" approach that is rooted within the pluralist theory of international politics is based on a set of assumptions that essentially attempt to dislodge the state as the primary referent of security, while placing greater emphasis on the interdependency and transnationalization of non-state actors.

The neo-realist approach to human security has been advocated by 'structural' or neo-realists such as Barry Buzan (1992) who argued in his seminal work, "People, State and Fear" that the straightjacket militaristic approach to security that dominated the discourse during the Cold War was simple minded and led to the underdevelopment of the concept. He subsequently broadened it to include political, economic, social and environmental threats, in addition to those that are militaristic. Although Buzan (1992) examines security from the three perspectives of the international system, the state, and the individual, he concluded that the most important and effective provider of security should remain the sovereign state. His analysis thus provides the most extensive contemporary examination available of human security from a state perspective and in league with a similar proposal by Clausewitz.

The critical or postmodernist approach to human security is reflected in the work of Ken Booth (1994) who advocated a broadened conceptualization of security that goes beyond a military determination of threats. But other advocates of postmodernist approach stresses quite explicitly that the state must be dislodged as the primacy referent of human security, and encompas s instead a wide range of non-state actors, such as individuals, ethnic and cultural groups, regional economic blocs, Multinational Corporations (MNCs) and Non-governmental Organizations (NGOs), and just about all humankind. In expanding the concept of security horizontally and vertically, Booth (1994) argues that human security is ultimately more important than state security. Put differently, the postmodernist conception of security does not equate state security with human security.

In Booth's view, states and implicitly governments must no longer be the primary referents of security because governments which are supposed to be the guardians of their people's security have instead become the primary source of insecurity for the many people who live under their sovereignty, rather than the armed forces of a neighboring country (Booth, 1994). This approach challenges the idea of a state as an effective and adequate provider of security to its people. Booth's approach attempts to address the non-military threats to human security and the fundamental difference lies in the way these analyses point to action. The broadening of security to conceive of more than just military threats raises the contentious question of what really is to be made secured. As a result, the ongoing security debate centres on the identification of a primary referent or unit of security has been central to an ongoing security debate.

Arguments for the state to remain the primary referent of security should not mean maintaining the state as the sole or unitary referent of security. But rather it means that the security of the state, in particular a state that is weak, should continue to remain primary, since the main aim is to build the capacity of the state to provide, and maintain security for its citizens (Aardt, 2007). In other words, although the conceptualization of security must make the security of people and human beings its end, the state, as the means, cannot be dislodged as the primary referent. After all, if the state is to provide and maintain security, it has to be secure itself or in the words of Buzan, it has to be or become a strong state (Aardt, 2006). This explanation needs some clarifications in an attempt to address the question of what constitutes a state.

Using the conventional interpretation, a state is made up of a government, people and territory. In other 
words, the whole (that is the state), comprising all its constituent parts, has a reciprocal relationship with the individual parts. The state cannot be secure if its constituent parts are weak or insecure in relation to other states, its elements will also be affected by such weakness or insecurity. Booth $(1994$, p.5) has argued that state security was used by governments that posed as guardians of their peoples' security, to cloak reality and hide what essentially was the security of their regime and its supporters and should therefore be dislodged as a primary referent of security. This argument need not mean the termination of the state per se as a referent of security, but rather that the type of state that has been unable to deliver security to its people should be questioned. It is such governments that do not allow the state to fulfill their functions of statehood that need to be eradicated and dislodged.

The new realist approach to security alongside state security is a twin referent in the theory and practice of security (Booth, 1994, p.4). In equating state and human security, Buzan (1992) makes reference to 'the fate of human collectivities' as being the primary object or referent of security. Human collectivities are the citizens of a state and the state becomes the referent of security as the representative institutions to, and security for, individuals. For Buzan (1992), citizens ultimately have to decide on the lesser of two evils that is either to accept the threats that arise in the absence of the state (Buzan, 1992). The assumption that whatever threats emanate from the state are likely to be of a lower magnitude than those arising in its absence, grows as society develops around the state, becoming increasingly dependent on it as a linchpin for social and economic structures of security. In seeking security, state and society are sometimes in harmony or opposed to each other but the bottom line is about survival (Buzan, 1992).

\section{A Perspective on Human Security and State Security}

The advent of globalization has made it imperative for the present international community to demand a new security paradigm because the security debate has dramatically changed since the inception of state security as advocated at the beginning of the $17^{\text {th }}$ century. According to the traditional idea, the state was to monopolize the rights and means to protect its citizens. State power and state security was established and expanded to sustain order and peace. But in the $21^{\text {st }}$ century, both the challenges to security and its protectors have become more complex. The state remains the fundamental purveyor of security and yet it often fails to fulfill its security obligations and at times become a source of threat to its own people. That is why attention must now shift from the security of the state to that of the people, human security.
Human security compliments state security, enhances human rights and strengthens human development. It seeks to protect people against a broad range of threats to individuals and communities and, further, to empower them to act on their own behalf. It also seeks to forge a global alliance to strengthen the institutional policies that link individuals and the state with a global world. Human security thus brings together the human elements of security, of rights and development. The Commission on Human Security's definition of human security as the means to protect the vital or core of all of human lives in ways that enhance human security means protecting fundamental freedoms that are the essence of life. It means protecting people from critical and pervasive threats and situations and using processes that build on people's strengths and aspirations. It equally involves creating political, social, environmental, economic, political, military and cultural systems that together give people the building blocks of survival, livelihood and dignity (UNDP, 2002).

The vital core of life is a set of elementary rights and freedoms people enjoy and what people consider being vital, although what they consider to be of essence of life and critically important varies across individuals and societies. That is why any concept of human security must be dynamic and equally why we refrain from proposing an itemized list of what makes up human security. As noted by the late Secretary-General of the UN, Kofi Annan, human security joins the main agenda items of peace, security and development. Human security is comprehensive in the sense that in its broadest form embraces far more than the absence of violent conflict encompasses human rights, good governance, access to education and health care and ensuring that each individual has opportunities and choices to fulfill his or her own potential. Every step in this direction is also a step towards reducing poverty, achieving economic growth and preventing conflict. It as well involves freedom of future generations to inherit a healthy natural environment, all of which are the interrelated building blocks of human and therefore national security (Annan, 2000).

Human security equally reinforces human dignity as people's horizon extends far beyond survival, to matters of love, culture and faith. Similarly, although protecting a core of activities and abilities is essential for human security, but that alone is not enough as human security must also aim at developing capabilities of individuals and communities to make informed choices and to act on behalf of cause and interests in many spheres of life. That is why human security starts from the recognition that people are the most active participants in determining their well being a in that process building 
people's efforts and strengthening what they do for themselves. Human security complements state security in the sphere of its concern for the individual and community rather than the state, the expansion of the range of actors beyond the state alone, the fact that to achieve human security people must not just be protected but empowered to fend for themselves and as well as the fact that menaces to people's security include threats and conditions that have not always been classified as threats to state security (Ogata, 2002).

In many respects, human security requires including the excluded and focuses on the widest possible range of people having enough confidence in their future, enough confidence that they can actually think about the next day, the next week, and the next year. Protecting and empowering people are thus about creating genuine possibilities for people to live in safety and dignity. Seen from this perspective, human security reinforces state security but does not replace it. This much was acknowledged by Imobighe (1998) when he averred that "if we accept the thesis of a people-oriented system, then our conceptualization of security must be based on human security. This line of thought must have influenced Nwolise (1988) when he observed that a country may have the best armed forces in terms of training and equipments, the most efficient custom men, the most active secret service agents and best quality prisons but yet be the most insecure nation in the world. To him, this would be as a result of defense and security problems within bad governments, alienated and suffering masses, ignorance, hunger, unemployment or even activities of foreign residents or companies.

Human security thus broadens the focus from the security of borders, to the lives of people and communities inside and across those borders. The idea is for people to be secured, not just for people to be secured, not just for territories within borders to be secured, against external aggression. And unlike traditional approaches that vest the state with full responsibility for state security, the process of human security involves a much broader spectrum of actors and institutions, especially people themselves.

The Challenges of Human Security in Sub-Saharan Africa and the Way Forward

In Africa, there is a high incidence of the twin phenomena of weak states and weak civil society alongside weak institutions with a tilt towards the emergence of strong men which have been witnessed over time. However, states have continued to be important actors politically and economically and within this context, the institutional and adminis trative short comings of governments, parliaments, judiciaries and security sectors, as well as low social and economic indicators, need to be addressed if any progress on human security is to be achieved. In furthering the cause of human security, the political will of the parties involved is crucial. Apart from a lack of capacity, lack of will has been a major constraint on progress in regional integration and the development of regional codes of conduct.

Accordingly, in designing a new strategy for confronting the critical challenges presented by the new international milieu, it must address the demands for peace and security. In fact, any effective method for tackling the challenge of the new era had to be one that could engender peace and security. This realization equally informed the land mark declaration on the political and economic situation in Africa and the fundamental changes taking place in the world by heads of state and government in 1990 (Aderinwale, 2001). That declaration not only presented an objective analysis of the state of affairs within the African continent, but also contained a range of suggestions on methods or procedures for changing the situation by tackling some of the apparently intractable challenges that confront the continent.

The leaders in that declaration committed to being fully aware that in order to facilitate the process of socio-economic transformation and integration, it is necessary to promote the popular participation of the peoples of the continent in the process of governance and development. They also acknowledged that democracy and development should go together and should be mutually reinforcing. The African Charter for Popular Participation in Development, signed by heads of state in Arusha, Tanzania in February 1990 also captured this new thinking. It moved a step further by pointedly maintaining that "we realize at the same time that responsibilities of achieving these objectives we have set, will be constrained as long as an atmosphere of lasting peace and stability does not prevail in our continent. We therefore renew our determination to work together towards the peaceful and speedy resolution of all the conflicts in the continent". Coming from an organization often labeled wrongly or rightly, a conservative club of African political oppressors, the declaration broke fresh grounds as the first frank and honest assessment of an African reality since the earliest wave of independence in Africa in the late 1950s and 1960s.

The Arusha Charter was followed by the Kampala Forum which remains another effort by leaders of the continent in addressing the problem of conflicts as bedrock for the attainment of human security. Tagged the Conference on Security, Stability, Development and Cooperation in Africa (CSSDCA), and in league with the Ota based African Leadership Forum (ALF), the Kampala Forum which attracted over five hundred people from all 
walks of life including trade union leaders, representatives of the private sector, peasants and presidents, students and professors, ministers and other political leaders as well as leaders from international intergovernmental and nongovernmental organizations brain stormed on possible ways of engendering peace and security in Africa. It rolled out proposals which have over the years come to be described as Africa's Magna Carta. The CSSDCA proposals also won the support of numerous African States, non-governmental organizations and influential individuals and opinion leaders, but failed to garner the full acceptance by the OAU although it remained a widely used resource base for policy formulation in some African states, and also in some regional and sub-regional organizations.

However, the ALF never lost hope, knowing too well that the period of activism is often long and sometimes frustrating as it stood by its original mission and vision. The liberating breakthrough eventually occurred in 1999, with Nigeria's return to democratic governance and the subsequent emergence of Olusegun Obasanjo as the country's president. This brought succour to the ALF founded by Obasanjo himself and a return of the CSSDCA proposals to the mainstream of policymaking. As a matter of fact, at the Algiers and Sirte OAU submits, President Obasanjo obtained support of his fellow African leaders for the resumption of the consideration of the CSSDCA, based on the Kampala document. The ALF was thereafter invited to become closely associated with the intergovernmental OAU-led process that was to consider the CSSDCA proposal (Obasanjo, 1993).

The recommendations of the Algiers summit meeting precipitated a series of events that eventually culminated in the adoption of the solemn Declaration by heads of state at the $36^{\text {th }}$ OAU summit in Lome, Togo. The full Declaration was presented in five parts with the introductory part followed by a list of general principles, thereafter a description of the specific principles and plan of action and an implementation mechanism. On the whole, the document captured the key issues of security, stability, development and cooperation (Aderinwale, 2001). The Declaration stipulates that peace, security and stability are the preconditions and the basis for development and cooperation in Africa. It also emphasized that the security, stability and development of African states are inseparably interlinked. The erosion of security and stability is thus one of the major causes of the crises that continue to plague African states, and one of the principal impediments to economic growth and human development in the continent.

The CSSDCA Declaration also noted that peace constitutes the basis of all wholesome human interactions and that with peace should go security. Lack of democracy, denial of personal liberty and abuse of human rights are causes of insecurity. The concept of security transcends military considerations and includes conflict prevention, containment and resolution, all of which relate to the aim of collective continental security. Security also embraces all aspects of society, including the economic, political and social dimensions of the individual, family and community, to take in national and regional stability. The declaration posited that the security of a nation must be construed in terms of the security of the individual citizen, not only to live in peace but also to have access to the basic necessities of life, to participate freely in the affairs of society and to enjoy fundamental human rights (Mandaza, 2005).

Justice makes it possible for a society to be governed in a level headed and equitable manner and enhances the basic principle that law in the land is supreme and above all personal interests. It ensures that elected politicians have respect for the system and maintain a state of order, transparency, accountability, social justice and the freedom of the people. This includes respect for variance in opinion and religious orientation. Justice on the other hand promotes cultural differences because it recognizes and accommodates plurality. Most significantly, it equally ensures that the spending and planning of the present generation is mindful of the interests of the generations yet unborn. It is only within the context of a just society that we can talk of peace. A complementary aim is the continuous improvement in the living conditions and prosperity, any attempt at building or creating a culture of peace cannot succeed. This was the message that CSSDCA sought to promote. The stability part of the CSSDCA outlines the imperative interaction between state and civil society as a means of achieving enduring political stability (Pisani, 2012). Under its guidelines, all African states were to be guided by strict adherence to the rule of law, popular participation in governance, respect for human rights and fundamental freedoms, while public policy making and execution should be both accountable and transparent, political organizations should not be based on religious, ethnic, regional or racial considerations, and violent and destructive fundamentalis $m$ in religious practice should be discouraged.

\section{CONCLUSION}

This paper examined the measures that could address the challenges of human security in Sub-Saharan Africa. It observed that the issue of security has moved away from the state centric paradigm to a focus on human development as the basis for a secure and stable society. Thus, it has become imperative that African states jettis on 
the top down approach of strengthening administrative structures or a state-central approach to security thinking. In fact, human security provides space for communitybased approaches to building stability through the civil society and international responses. However, an adequate conceptualization of human security for African states must link human security with human development while economic development must also be at the top of the institutional agenda, since development and security are two sides of the coin. It must be noted that non-state actors do not have the power to bring about large scale development or to resolve the new and emerging security threats alone without any state assistance. It is only academic to conceive of rudimentary security and development without strong, legitimate states, consequently, in the context of African soft states, strengthening the state is a necessary precondition for the institutionalization of peace and security. The truth remains that Africa states will have to remain interventionist to build the institutional capacity to manage non-traditional security threats that affect the people of the continent. The onus therefore is on the leadership of the various states in the continent to apply all measures that can engender human development.

Given the above conclusion this paper recommends the following:

(i) African states must develop national and international norms, processes and institutions which must address insecurity in ways that are systematic and not make shift, comprehensive not compartmentalized, preventive and nonreactive. This is necessary because human security connects several kinds of freedom, such as freedom from want and fear as well as freedom to take action on one's own behalf. Thus, ensuring human security expands the real freedoms that people enjoy and protecting people's security requires identifying and preparing for events that could have severe and widespread consequences. In fact, protecting people entails upholding their basic rights and freedom.

(ii) Human capacity building must be promoted by states in the continent in a way that could help establish a strategy for the prevention of HIV/AIDS as well as other contagious diseases. The leaders should mobilize and act as catalyst for international cooperation in support of initiatives by African member states; and promote the active participation of communities and representatives of civil society in the planning and implementation of development programs, thereby ensuring security for the most vulnerable populations. Even though the infrastructure of protection may be imperfect, it can help to counter threats, mitigate their force, support people threatened and create a more stable environment for the African populace.

(iii) Finally, there is need for African citizens to hold their leaders accountable particularly with regards to the use of the various resource endowments in the continent so as to ensure the deployment of such resources for the development of the continent. Equally, the leaders should be made to respect the rule of law and the fundamental human rights as bedrock for human capital development.

\section{REFERENCES}

[1] Aardt, M. V. (2007). The Emerging Security Framework for Southern Africa: Regime or Community? Strategic Review for Southern Africa, XIX.

[2] Aardt, M.V. (2006). Doing Battle with Security: A Southern African Approach, South African Journal of International Affairs, Vol.3, No.2, pp.13-28.

[3] Aderinwale, A. (2001). Bridging the Gap Between the State and the Civil Society: The Role of Regional Institutions in Constitution Making Processes, The CSSDCA Framework, presentation at the CDD Conference on Constitutionalism in Africa, Cape Town, June.

[4] Annan, K. (2000). Secretary General Salutes International Workshop on Human Security in Mongolia,Two Day Session in Ulaanbaatar, May $8-10$.

[5] Annan, K. (2001). An Address to the $37^{\text {th }}$ Summit of the Organization of African Unity (OAU) in Lusaka, Zambia, July.

[6] Booth, K. (1994). A Security Regime in Southern Africa: Theoretical Considerations, Southern African Perspectives No.30, CSAS.

[7] Buzan, B. (1991). New Patterns of Global Security in the21st Century, International Affairs, Vol.67, No.3, pp 431-451.

[8] Buzan, B. (1992). People, States and Fear: An Agenda for International Security Studies in the Post-Cold War Era, New York: Harvester Wheat Sheaf.

[9] Henk, D. (2008). Security: A New African Paradigm, Security in Africa Occasional Paper No.1, Accessed from www.uz.ac.zwlunits/cds/occasional/paper on 23 September, 2018.

[10] Hutchful, E. \& Fayemi, K. (2004). Security System Reforms in Africa in A survey of Security System 
Reform and Donor Policy: Views from Non-OECD countries, DAC Policy Paper on Security System Reform and Governance, Paris :OECD.

[11] Imobighe, T.M. (1998). The Management of National, Ekpoma: Edo State University Publishing House.

[12] Mandaza, I. (2005). Peace and Security, Regional Cooperation and Economic Integration, SAPEM, Vol.8, No.7, pp.29-31.

[13] Nwolise, O.B.C. (1988). Nigeria's Defence and Security Today, in Eleazu, U. (ed). Nigeria: The First Twenty Five Years, Ibadan: Heinemann.

[14] OAU (1991). Towards a Conference on Security, Stability, Development and Cooperation in Africa, Kampala, Uganda.

[15] Obasanjo, O. (1993). Africa in Search of Common Values, Ota: ALF Publications.

[16] OECD (2001). Helping Prevent Violent Conflict, Paris: OECD.

[17] Ogata, S. \& Sen, A.(2003). Human Security Now, CHS Final Report, New York.

[18] Ogata, S. (2002). From State Security to Human Security. The Ogelen Lecture Series, Brown University, Providence, Rhodes Island, $26^{\text {th }}$ May.

[19] Ogata, S. (2002). Introductory Remarks as Co-chair, Commission on Human Security, Ashgabat Round Table, April.

[20] Pisani, A.D. (2012). Security and Peace in a PostApartheid Southern Africa, International Affairs Bulletin, Vol.16, No.3, pp.29-31.

[21] Rugumamu, S.(1993).Post Cold War Peace and Security: Prospects in South Africa, SAPES Occasional Paper Series No.5, Harare.

[22] Thompson, L. (2000). Theoretical Approaches to Security and Development, ISS Monograph No.50, Netherland.

[23] United Nations Development Program, UNDP (2002). Human Development Report, New York: Oxford University Press. 